STUDY TO OPTIMIZE Cr-MO STEELS TO RESIST

HYDROGEN AND TEMPER EMBRITTLEMENT

B. J. Shaw

Ju1y 23, 1980

Quarterly Report No. 5

(August 15, 1979 to November 15, 1979)

Westinghouse Electric Corporation Research and Development Center Pittsburgh, Pennsylvania 15235

Contract No. DE-AC05-780R13513

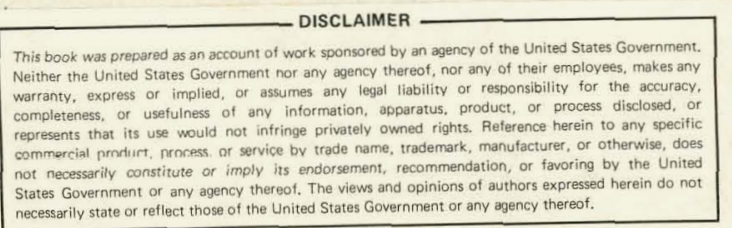

U.S. Department of Energy

Division of Coal Conversion

DOE Project Manager: Mr. E. E. Hoffman

(W) Program Manager: Dr. Bevil J. Shaw

Effective Date of Contract: August 17, 1978

Contract Expiration Date: August 16, 1981 


\section{DISCLAIMER}

This report was prepared as an account of work sponsored by an agency of the United States Government. Neither the United States Government nor any agency Thereof, nor any of their employees, makes any warranty, express or implied, or assumes any legal liability or responsibility for the accuracy, completeness, or usefulness of any information, apparatus, product, or process disclosed, or represents that its use would not infringe privately owned rights. Reference herein to any specific commercial product, process, or service by trade name, trademark, manufacturer, or otherwise does not necessarily constitute or imply its endorsement, recommendation, or favoring by the United States Government or any agency thereof. The views and opinions of authors expressed herein do not necessarily state or reflect those of the United States Government or any agency thereof. 


\section{DISCLAIMER}

Portions of this document may be illegible in electronic image products. Images are produced from the best available original document. 


\section{NOTICE}

This report was prepared as an account of work sponsored by an agency of the United States Government. Neither the United States Government nor any agency thereof, nor any of their employees makes any warranty, expressed or implied, or assumes any level of liability or responsibility for any third party's use or the results of such use of any information, apparatus, product or process disclosed in this report or represents that its use by such third party would not infringe privately owned rights. 


\title{
STUDY TO OPTIMIZE Cr-MO STEELS TO RESIST HYDROGEN AND TEMPER EMBRITTLEMENT
}

\author{
B. J. Shaw \\ Westinghouse R\&D Center \\ 1310 Beulah Road \\ Pittsburgh, Pennsylvania 15235
}

\begin{abstract}
This report gives the results of tests designed to measure the threshold stress intensity ( $\mathrm{K}_{\text {IscC }}$ ) in $\mathrm{H}_{2} \mathrm{~S}$ of the peak hardness zone in the HAZ of welds in $2 \frac{1}{4} \mathrm{Cr}-1$. Mo plate. Difficulty was encountered because of a variability in the location of the peak hardness zone relative to the weld-base interface. There are indications that $\mathrm{K}_{\mathrm{Iscc}}$ could be significantly below $80 \mathrm{ksi} \sqrt{\mathrm{in}}$ but the absolute value could not be determined from the current tests. Details of the forging process and the status of the program are also presented.
\end{abstract}


1. OBJECTIVES OF PROGRAM . . . . . . . . . . . . . . . . 1

2. STATUS OF PROGRAM . . . . . . . . . . . . . . . . . . 3

3. HEAT AFFECTED ZONE STUDY (HAZ). . . . . . . . . . . . . 4

4. FORGING OF LABORATORY HEATS . . . . . . . . . . . . . . . 8

5. ACKNOWLEDGMENTS . . . . . . . . . . . . . . . . . . . . . . 9

6. REFERENCES. . . . . . . . . . . . . . . . . . 10 


\title{
STUDY TO OPTIMIZE Cr-MO STEELS TO RESIST HYDROGEN AND TEMPER EMBRITTLEMENT
}

\author{
B. J. Shaw \\ Westinghouse R\&D Center \\ 1310 Beulah Road \\ Pittsburgh, Pennsylvania 15235
}

\section{OBJECTIVES OF PROGRAM}

This program is designed to assess the hydrogen embrittlement susceptibility and temper embrittlement susceptibility of Cr-Mo steels. In Phase I of the program, the hydrogen embrittlement susceptibility of commercial $2 \frac{1}{4} \mathrm{Cr}-1$ Mo steels is studied. This phase has two components: (a) the hydrogen embrittlement susceptibility of plate or forged steel, and (b) the susceptibility of the peak hardness zone in the heat affected zone (HAZ) in a weld. Since only a small amount of weld material was available, plate steel was heat treated to a strength level comparable with that of the peak hardness in the HAZ for simulation tests. Phase II of the program is a study of the effect of alloying elements in the Cr-Mo steel, using a set of 32 laboratory steels with compositions arranged according to a statistical design. The alloying variables in this set are Mo, $\mathrm{Cr}, \mathrm{Mn}, \mathrm{Si}, \mathrm{C}$ and $\mathrm{P}$. The steels are to be assessed for hydrogen embrittlement and temper embrittlement at two strength levels, one corresponding to typical strength levels used commercially and the second corresponding to the peak hardness in the HAZ. The hydrogen embrittlement data generated in Phase II will be compared with that of Phase $I$. The temper embrittlement data will be compared with data from the American Petroleum Institute (API) program on temper embrittlement of commercial $2 \frac{1}{4} \mathrm{Cr}-1$ Mo steels. The main emphasis is on 
the evaluation of the effect of the alloying elements on the two modes of embrittlement. A small effort will be expended on synergistic effects, i.e. the effect of prior temper embrittlement on hydrogen embrittlenient.

The results of the program will allow for a determination of the optimum $\mathrm{Cr}$-Mo steel compositions for resistance to hydrogen and temper embrittlement. 


\section{STATUS OF PROGRAM}

The logic flow diagram for the program is given in Fig. 1, and the objectives are given in Table I. In Phase I of the program (1.1.1 to 1.1.3) the main emphasis was on the evaluation of hydrogen embrittlement susceptibility of API commercial steels. Very early in this part of the program it became evident that the proposed test technique, the fatigue pre-cracked Charpy rising load test in $\mathrm{H}_{2} \mathrm{~S}$, was not a viable means of assessing the threshold stress intensity ( $\mathrm{K}_{\text {Iscc }}$ ) in the environment. Moreover, it was not a reasonable method for approximately estimating $\mathrm{K}_{\mathrm{Iscc}}$ for relative screening purposes. This was discussed in detail in the first annual report. (1) A new issue in the program was therefore to evolve a means of assessing the hydrogen embrittlement characteristics of the Cr-Mo steel. The method for testing the steels heat treated to a strength level comparable with that of the HAZ (Rockwell B hardness 97) has been established. Thus objective 1.1 .3 in Table II is essentially completed. Since the lower strength steels showed resistance to hydrogen embrittlement in our current test using commercial high purity $\mathrm{H}_{2} \mathrm{~S}$, a secondary study has been initiated to evaluate the effect of strength level (Table III).

In Phase II of the program the forging of the 32 laboratury steels has been completed and the tempering conditions (time, temperature) for two strength levels are being evaluated. 


\section{HEA'I AFFECTED ZONE STUDY (HAZ)}

\subsection{Introduction}

The primary objective of this part of the program, identified as 1.2 in the logic flow diagram, was to characterize the hydrogen embrittlement susceptibility of the HAZ in three commercial samples of Cr-Mo steel. Three large welds were selected from the American Petroleum Institute (API) stock. These samples, identified as 25, 62 and 63, were large enough to make $2 \mathrm{~T}$-WOL specimens with the notches of the specimens lying in the plane of the peak hardness zone of the HAZ. The type of weld and the post-weld heat treatments are listed in Table IV.

In a second series of tests Charpy impact curves were generated to establish the Fracture Appearance Transition Temperature (FATT) and the $40 \mathrm{ft}-1 \mathrm{~b}$ Transition Temperature ( $40 \mathrm{ft}-1 \mathrm{~b} \mathrm{TT}$ ) for the HAZ peak hardness zone and the unaffected plate. Similar tests were also performed on sample 62 in a temper embrittled condition $\left(875^{\circ} \mathrm{F}\right.$ for $1000 \mathrm{hr}$ ).

\subsection{Experimental Procedure}

The samples were macroetched in order to reveal the location and orientation of the welds. Specimen blanks were then cut, polished and etched in $2 \%$ Nital to reveal the weld interfaces and HAZ (Fig. 2). The peak hardness zone in the HAZ was identified by taking diamond pyramid microhardness measurements on each sample across the weld interface. Knoop hardness measurements were not taken because of size limitations of the instrument. A typical hardness profile, using knoop measurements, is shown in Fig. 3.

The location and orientation of the peak hardness zone (PHZ) was scribed on each sample blank and the tip of the notch of the 
machined 2T-WOL specimens was located in the plane of the PHZ. Side grooves, 0.25 in deep, were machined on each specimen to eliminate plane stress zones and also to confine the crack to the PHZ. The notches in the Charpy impact specimens were similarly located. Charpy specimens were not side-grooved.

The 2T-WOL side-grooved specimens were tested in 50 psig (446 KPa) of commercial high purity $\mathrm{H}_{2} \mathrm{~S}$. The modified test.procedure, which has been described in detail in an earlier report, (1) was employed to assess the hydrogen embrittlement susceptibility of the PHZ. This procedure employs pre-cracking by cyclic loading at $1 \mathrm{~Hz}$ in the $\mathrm{H}_{2} \mathrm{~S}$ environment to induce an unoxidized sharp crack. The method is designed primarily to reduce the incubation time to a minimum. Once the crack is propagating under cyclic loading, the stress intensity is raised slightly and the specimen held at a constant displacement. This is achieved by LVDT displacement control of the servohydraulic system which loads the specimen. The simulated bolt load test (i.e. constant displacement) is then monitored for load drop, which indicates crack growth. By measuring the compliance of the specimen (i.e. by unloading to measure $V / P$, where $V$ is displacement and $P$ is load), crack growth can also be assessed. When the load no longer decreases, the crack has arrested and a measure of $\mathrm{K}_{\mathrm{Iscc}}$ is obtained from the actual crack length and the final applied load. The side grooves in the specimens were introduced to eliminate plane-stress pinning of the crack, which is a severe problein in luw slrenglh slets.

\subsection{Results and Discussion}

(a) $\mathrm{H}_{2} \mathrm{~S}$ Environmental Tests

Tests on the PHZ of specimen no. 62 were carried out by the above procedure. Whereas crack advance could be obtained under cyclic loading, little or no crack advance was obtained under constant displacement until the crack was approximately 0.5 in $\left(1.3 \times 10^{-2} \mathrm{~m}\right)$ long. At this point the crack grew in the constant displacement condition to an estimated $k_{\text {arrest }}$ of the order of $85 \mathrm{ksi} \sqrt{\mathrm{in}}\left(93.5 \mathrm{MN} / \mathrm{m}^{3 / 2}\right)$. 
After breaking the specimen open, it was found that the crack had advanced out of the PHZ into the plate (or away from the weld). Figure 4 shows an overview of the fracture surface in which shear lines can be seen on the sides of the specimen due to the central part of the crack growing out of the side groove plane. Figure 5 is a cross-sectional view of the center of the cracked specimen. It can be seen that the crack moved away from the plane of the notch by approximately .025 in $\left(6 \times 10^{-4} \mathrm{~m}\right)$. This distance is comparable with the distance of the PHZ from the weld fusion line shown in Fig. 3.

The test underlines one of the difficulties in testing the PHZ adjacent to a weld. Clearly there is a variability in the location of the PHZ relative to the weld interface. Consequently, the location of the crack notch and side grooves may be correct for the initial crack only. Unfortunately, if the side grooves are not incorporated in the specimen design, the test data is confounded by plane-stress pinning of the crack.

In earlier tests in this study ${ }^{(1)}$ on simulated $\mathrm{HAZ}$ (higher strength leve1) $2 \frac{1}{4} \mathrm{Cr}-1$ Mo steel, the $\mathrm{K}_{\text {arrest }}$ of a smooth-sided $3 \mathrm{~T}-\mathrm{CT}$ was compared with that of a side-grooved $2 \mathrm{~T}-\mathrm{CT}$. The difference in $\mathrm{K}$ arrest $\left(110 \mathrm{MN} / \mathrm{m}^{3 / 2}\right.$ versus $22 \mathrm{MN} / \mathrm{m}^{3 / 2}$ for the latter) is due to the plane stress pinning in the $3 \mathrm{~T}-\mathrm{CT}$. It is clear that the out-of-plane crack advance in the $\mathrm{PHZ}$ test of specimen 62 resulted in side pinning of the crack. Conservatively then, the $\mathrm{K}$ arrest for the PHZ in this oample should be less Lhan half of the original estimate, even though an actual measurement could not be obtained.

Sample no. 25 was tested in the same way as no. 62 , with essentially identical results, except that the measured $\mathrm{k}$ arrest was of the order $60 \mathrm{ksi} \sqrt{\mathrm{in}}\left(66 \mathrm{MN} / \mathrm{m}^{3 / 2}\right)$. Again, the actual threshold stress intensity for the PHZ should be considerably less.

Sample no. 63 exhibited the same kind of load-displacement behavior as nos. 62 and 25. Consequently, it was assumed, since there was increasing resistance to cracking as the crack propagated, that the 
crack was growing out of the side groove plane. This specimen was not broken open since an attempt will be made at a later date to locate a smaller compact tension specimen around the tip of the present crack in the $2 \mathrm{~T}-\mathrm{WOL}$.

\section{(b) Charpy Impact Tests}

The locations of specimens taken from samples 25, 62 and 63 are shown in Fig. 6. The data from the Charpy impact curves is given in Table VI. In all four sets of data it is clear that the transition temperature in the $\mathrm{PHZ}$ is less than that of the base plate. After temper embrittlement of sample 63, the HAZ showed a greater shift ( $\triangle$ FATT) than the base plate. The impact energy at room temperature is listed since this could have some bearing on the crack path. For example, sample no. 25 has a significantly lower impact energy in the base plate than in the HAZ. Consequently, a crack in the HAZ might be expected to shift out of the HAZ into a lower energy path in the plate. This factor is not significant in samples 62 and 63.

The variability in the location of the $\mathrm{PHZ}$ in the HAZ was discussed above. Even taking this into account the crack advanced further from the approximate PHZ area than would be anticipated in specimen 62. The room temperature impact energy of the plate in this specimen was comparable or greater than that of the HAZ, hence the crack would not be expected to advance into the plate as it might in specimen 25 (Table VI). The evidence therefore suggests that the component of the HAZ most susceptible to hydrogen embrittlement could lie outside the $\mathrm{PHZ}$. 


\section{FORGING OF LABORATORY HEATS}

The cast heats were 12 in " long tapered square ingots with side dimensions of approximately 5 in at the top and 4 in at the bottom. The hot tops were removed prior to forging leaving approximately 10 in long ingots. The forging temperature was between 1100 and $1200^{\circ} \mathrm{C}$. In the first stage of forging the ingots were reduced from a 4 to 5 in side dimension to $3.5 \mathrm{in.}$ The 17-13 in length ingot was then sectioned into 3 pieces. Two pieces from the bottom, 5.5 in long, were upset in the second stage of forging to produce pieces 2.25 in thick by 5.5 in square. These pieces are large enough to make a 2T-Compact Tension $(C \cdot T)$ specimen. The remaining piece, $6-7$ in long by 3.5 by 3.5 in, was forged from one side to produce a "pancake" approximately 1.125 in thick by 6 by 9 in. It is planned to take 1T-CT specimens and Charpy specimens from these pieces.

Since problems were encountered in the initial stages of making these heats, due to the use of larger than normal moulds for the apparatus, a redundant heat was employed for a trial run on the forging routine. The cross sectlons of the forged material showed a uniform structure throughout (Fig. 7). The 32 heats for the main part of the program were therefore identically fuiged. The forging was dune al Butler Forge, Butler, PA.

${ }_{1 \text { in }}=2.54 \times 10^{-2} \mathrm{~m}$. 


\section{ACKNOWLEDGMENTS}

Metallography and hardness measuremerts were taken by R. J. Burland. The environmental tests were conducted by R. J. Smykal under the general supervision of L. Ceschini. The interest and critical comments of Dr. J. M. Wells are gratefully acknowledged. 


\section{REFERENCES}

1. B. J. Shaw and E. W. Johnson, "Study to Optimize Cr-Mo Steels to Resist Hydrogen and Temper Embrittlement," DOE Contract ET-78-C-01-3050, First Annual Report, Dec. 1979.

PERMANENT RECORD BOOK ENTRIES

Fig. Book No. 208613, pp. 27-28 
TABLE I - List of Primary Tasks, Schedule and Status of the Cr-Mo Steel Optimization Program

\begin{tabular}{|c|c|c|c|}
\hline & & $\begin{array}{l}\text { Comments } \\
\text { or Start Date }\end{array}$ & $\begin{array}{c}\text { Projected } \\
\text { Completion } \\
\text { Date } \\
\end{array}$ \\
\hline Phase I & Evaluation of API Commercial Material & Started & 9.80 \\
\hline Task 1.1 & Evaluation of Simulated HAZ Commercial Material & Started & 9.80 \\
\hline $\begin{aligned} \text { Item } & 1.1 .1 \\
& 1.1 .2 \\
& 1.1 .3 \\
& 1.1 .4 \\
& 1.1 .5\end{aligned}$ & $\begin{array}{l}\text { Material Characterization and Heat Treatment } \\
\text { Machining of Test Specimens } \\
\text { Evaluation of Hydrogen Embrittlement Susceptibility } \\
\text { Evaluation of Temper Embrittlement Susceptibility } \\
\text { Correlatior., Analysis and Topical Report }\end{array}$ & $\begin{array}{l}\text { Finished } \\
\text { Fintshed } \\
\text { Table II } \\
\begin{array}{c}11.79 \\
3.80\end{array}\end{array}$ & $\begin{array}{l}6.79^{*} \\
5.79 \\
6.81^{*} \\
4.80^{\star} \\
6.80\end{array}$ \\
\hline Task 1.2 & Evaluation of Actual HAZ Commercial Materlal & Started & 9.80 \\
\hline 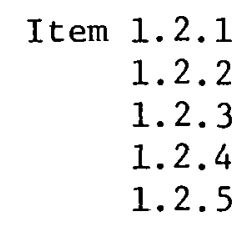 & $\begin{array}{l}\text { Material Selection and Characterization } \\
\text { Machining of Test Specimens } \\
\text { Evaluation of Hydrogen Embrittlement Susceptibility } \\
\text { Fractography and Hardness Evaluation } \\
\text { Correlation, Analysis and Topical Report }\end{array}$ & $\begin{array}{l}\text { Finished } \\
\text { Finished } \\
\text { Finished } \\
\text { Continuing } \\
\quad 4.80\end{array}$ & $\begin{array}{l}8.79 * \\
7.79 * \\
3.80 \\
6.80 \\
9.80 *\end{array}$ \\
\hline $\begin{array}{l}\text { Phase II } \\
\text { Task } 2.1\end{array}$ & $\begin{array}{l}\text { Evaluation of Laboratory Statistical Compositions } \\
\text { Procurement of Statistical Composition Material }\end{array}$ & $\begin{array}{l}\text { Started } \\
\text { Started }\end{array}$ & $\begin{array}{r}9.81 \\
12.79\end{array}$ \\
\hline $\begin{array}{r}\text { Item } 2.1 .1 \\
2.1 .2 \\
2.1 .3 \\
2.1 .4 \\
2.1 .5\end{array}$ & $\begin{array}{l}\text { Design of Statistical Composition Material } \\
\text { Casting of Jaboratory Alloys } \\
\text { Processing of Laboratory Alloys } \\
\text { Materials Characterization } \\
\text { Development of Hardness and HT Schedules }\end{array}$ & $\begin{array}{l}\text { Finished } \\
\text { Finished } \\
\text { Finished } \\
11.79 * \\
\text { Started } 6.79\end{array}$ & $\begin{array}{r}10.78 \\
5.79 * \\
8.79 * \\
4.80 * \\
4.80 *\end{array}$ \\
\hline Task 2.2 & Specimen Preparation & $12.79 *$ & $6.80 *$ \\
\hline $\begin{aligned} \text { Item } 2.2 .1 \\
2.2 .2\end{aligned}$ & $\begin{array}{l}\text { Machining of Specimens } \\
\text { Specimen HT and Precracking }\end{array}$ & $\begin{array}{r}10.79 \\
3.80\end{array}$ & $\begin{array}{l}6.80^{*} \\
9.80\end{array}$ \\
\hline Task 2.3 & Evaluation of Hydrogen Embrittlement Susceptibility & 7.80 & 6.81 \\
\hline Task 2.4 & Evaluation of Temper Embrittlement Susceptibility & 7.80 & 6.81 \\
\hline Task 2.5 & Statistical and Summary Analysis and Final Report & $7.81^{\circ}$ & 9.81 \\
\hline
\end{tabular}

\footnotetext{
* Revised dates.
} 
TABLE II - Modification Task for 1.1.3 in Phase I

\begin{tabular}{|c|c|c|c|}
\hline & & $\begin{array}{l}\text { Comments or } \\
\text { Start Date }\end{array}$ & $\begin{array}{c}\text { Projected } \\
\text { Completion } \\
\text { Date } \\
\end{array}$ \\
\hline Task $1.1 .3(\mathrm{a})$ & $\begin{array}{l}\text { Long Term Bolt Loaded Tests } \\
\text { on Low Strength Steels }\end{array}$ & & \\
\hline (i) & Machine specimens & Finished & -- \\
\hline (ii) & $\begin{array}{l}\text { Air pre-fatigue crack speci- } \\
\text { mens and shim load } \\
\text { (equivalent to bolt load) }\end{array}$ & Finished & --- \\
\hline (iii) & $\begin{array}{l}\text { Periodical inspection for } \\
\text { crack advance }\end{array}$ & Continuing & 6.81 \\
\hline Task $1.1 .3(\mathrm{~b})$ & $\begin{array}{l}\text { Evaluation of Testing Pro- } \\
\text { cedures to Assess Hydrogen } \\
\text { Embrittlement Resistance }\end{array}$ & & \\
\hline (i) & $\begin{array}{l}\text { Modification of compact } \\
\text { tension specimens to elimi- } \\
\text { nate plant stress zones }\end{array}$ & Finished & -- \\
\hline (ii) & $\begin{array}{l}\text { Modification of testing } \\
\text { procedure to reduce incuba- } \\
\text { tion time and measure } \\
\text { crack arrest stress inten- } \\
\text { sity }\end{array}$ & Finished & --- \\
\hline
\end{tabular}


TABLE III - Additional Tasks Introduced in Phase I, Item 1.1.3

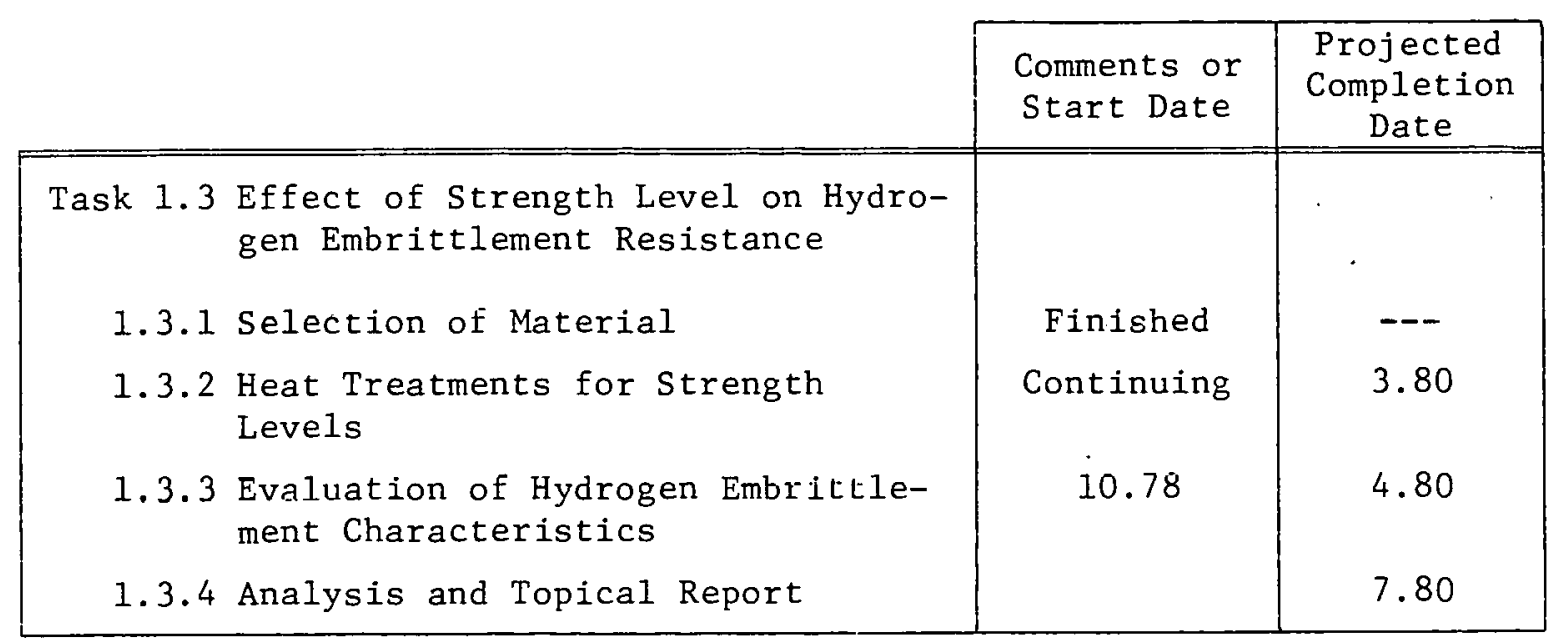


TABLE IV - Post Weld Heat Treatments of Weld Samples

\begin{tabular}{|c|l|}
\hline Sample No. & \\
\hline 25 & $2 \frac{1}{4} \mathrm{Cr}-1 \mathrm{Mo}$ Submerged Arc Weld \\
& $1100^{\circ} \mathrm{F}-8 \mathrm{hr}$ \\
& $1200^{\circ} \mathrm{F}-15 \mathrm{hr}$ \\
& $1275^{\circ} \mathrm{F}-7 \mathrm{hr}$ \\
& Cool $50^{\circ} \mathrm{F} / \mathrm{hr}$ \\
62 & $2 \frac{1}{4} \mathrm{Cr}-1 \mathrm{Mo}$ Submerged Arc Weld \\
& $1274^{\circ} \mathrm{F}-24 \mathrm{hr}$ - Furnace Cool \\
63 & $2 \frac{1}{4} \mathrm{Cr}-1$ Mo Shielded Metal Arc Weld \\
& $1274^{\circ} \mathrm{F}-24 \mathrm{hr}$ - Furnace Cool
\end{tabular}

Conversions: $1 \mathrm{hr}=3.6 \times 10^{3} \mathrm{~s}$.

$t^{\circ} \mathrm{C}=\left(t^{\circ} \mathrm{F}-32\right) / 1.8$ 
TABLE V - Comparison of the Peak Hardness in the HAZ With the Base Metal Hardness Beyond the HAZ

\begin{tabular}{|c|c|c|c|c|c|c|}
\hline \multirow{4}{*}{$\begin{array}{c}\text { API Sample } \\
\text { No. }\end{array}$} & \multicolumn{3}{|c|}{ Peak Hardness in HAZ } & \multicolumn{3}{c|}{ Base Metal } \\
\cline { 2 - 7 } & $\begin{array}{c}\text { Measured } \\
\text { Pyramid } \\
\text { Hardness }\end{array}$ & $\begin{array}{c}\text { Equivalent } \\
\text { R }_{B}\end{array}$ & $\begin{array}{c}\text { Equivalent } \\
\text { UTS, ksi }\end{array}$ & $\begin{array}{c}\text { Measured } \\
\text { Diamond } \\
\text { Pyramid } \\
\text { Hardness }\end{array}$ & $\begin{array}{c}\text { Equivalent } \\
\text { R}_{B}\end{array}$ & $\begin{array}{c}\text { Equivalent } \\
\text { UTS, ksi }\end{array}$ \\
\hline \hline 25 & 222 & 95 & 101 & 150 & 79 & 71 \\
$6 \hat{2}$ & 227 & 96 & 103 & 160 & 82 & 75 \\
63 & 214 & 94 & 100 & 190 & 90 & 89 \\
\hline
\end{tabular}

RB - Rockwell B Hardness Value.

OTS - Ultimate Tensile Strength.

HAZ - Heat Affected Zone.

$1 \mathrm{ksi}-6.895 \mathrm{MPa}$. 
TABLE VI - Fracture Appearance Transition Temperatures and $40 \mathrm{ft}-1 \mathrm{~b}$ Transition Temperatures from the Peak Hardness Zone of the HAZ and Base Plate of Samples 25, 62 and 63

\begin{tabular}{|c|c|c|c|c|}
\hline $\begin{array}{c}\text { Sample } \\
\text { No. }\end{array}$ & Location & $\begin{array}{c}\text { FATT } \\
{ }^{\circ} \mathrm{F}\end{array}$ & $\begin{array}{c}40 \mathrm{ft}-1 \mathrm{~b} \\
{ }^{\circ} \mathrm{F}\end{array}$ & $\begin{array}{c}\text { Room } \\
\text { Temperature } \\
\text { Impact Energy } \\
\text { ft-1bs }\end{array}$ \\
\hline \hline 25 & Plate & 150 & 130 & 10 \\
62 & HAZ & 30 & 0 & 70 \\
& Plate & 30 & 5 & 100 \\
63 & HAZ & 0 & -5 & 85 \\
& Hlate & 10 & 5 & 100 \\
$63^{*}$ & HAZ & -30 & -75 & 100 \\
& Plate & 30 & 0 & 90 \\
& HAZ & 10 & -40 & 95 \\
\hline
\end{tabular}

* Temper embrittled at $875^{\circ} \mathrm{F}$ for $1000 \mathrm{hr}$.

Conversions: $\quad t^{\circ} \mathrm{C}=\left(t^{\circ} \mathrm{F}-32\right) / 1.8$. 
FICURE I LOGIC FLOW DIAGRAM FOR THE OPTIMIZATION OF Cr-MO STEEL COMPOSITION

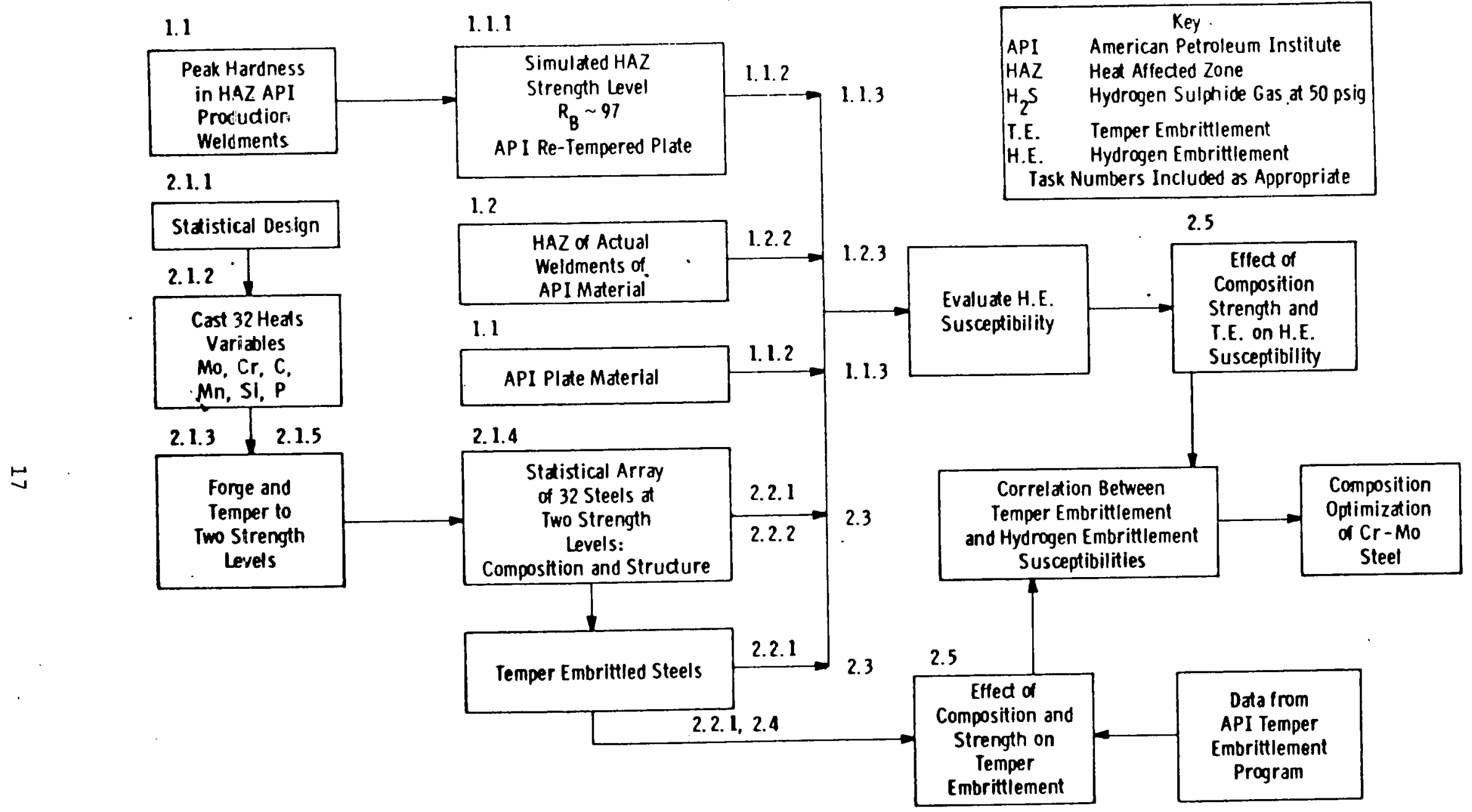




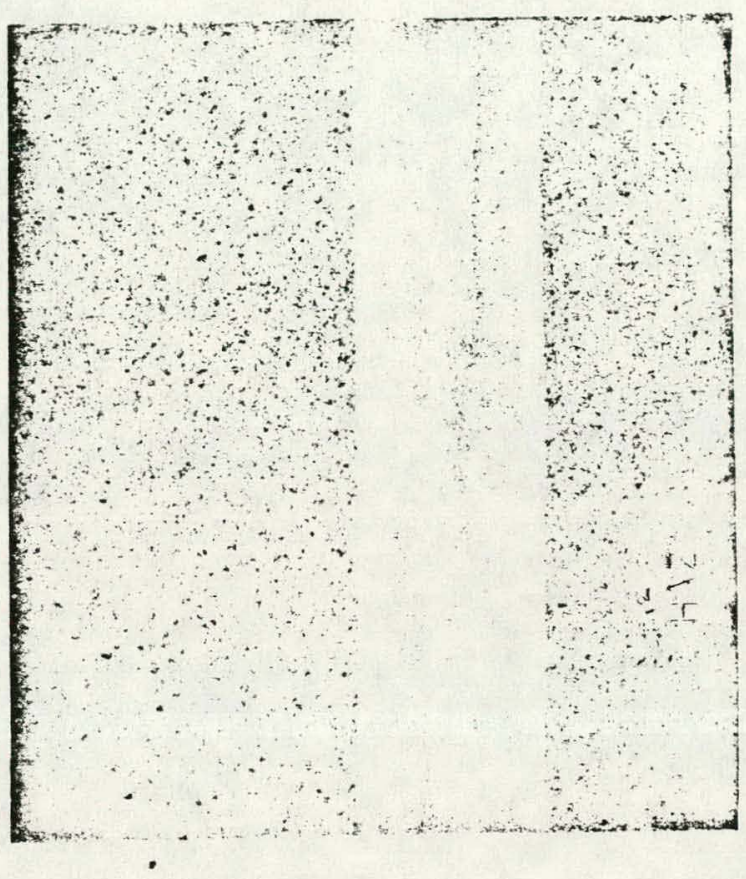

$x^{\frac{1}{2}}$

Fig. 2 The section of sample no. 62 after macroetching in $2 \%$ Nital. The notch of the 2T-WOL specimen machined from this section was placed in the peak hardness zone on the left of the weld. 
Sample No. 62, $2 \frac{1}{4} \mathrm{Cr}$-1Mo, Submerged Arc Weld, mm

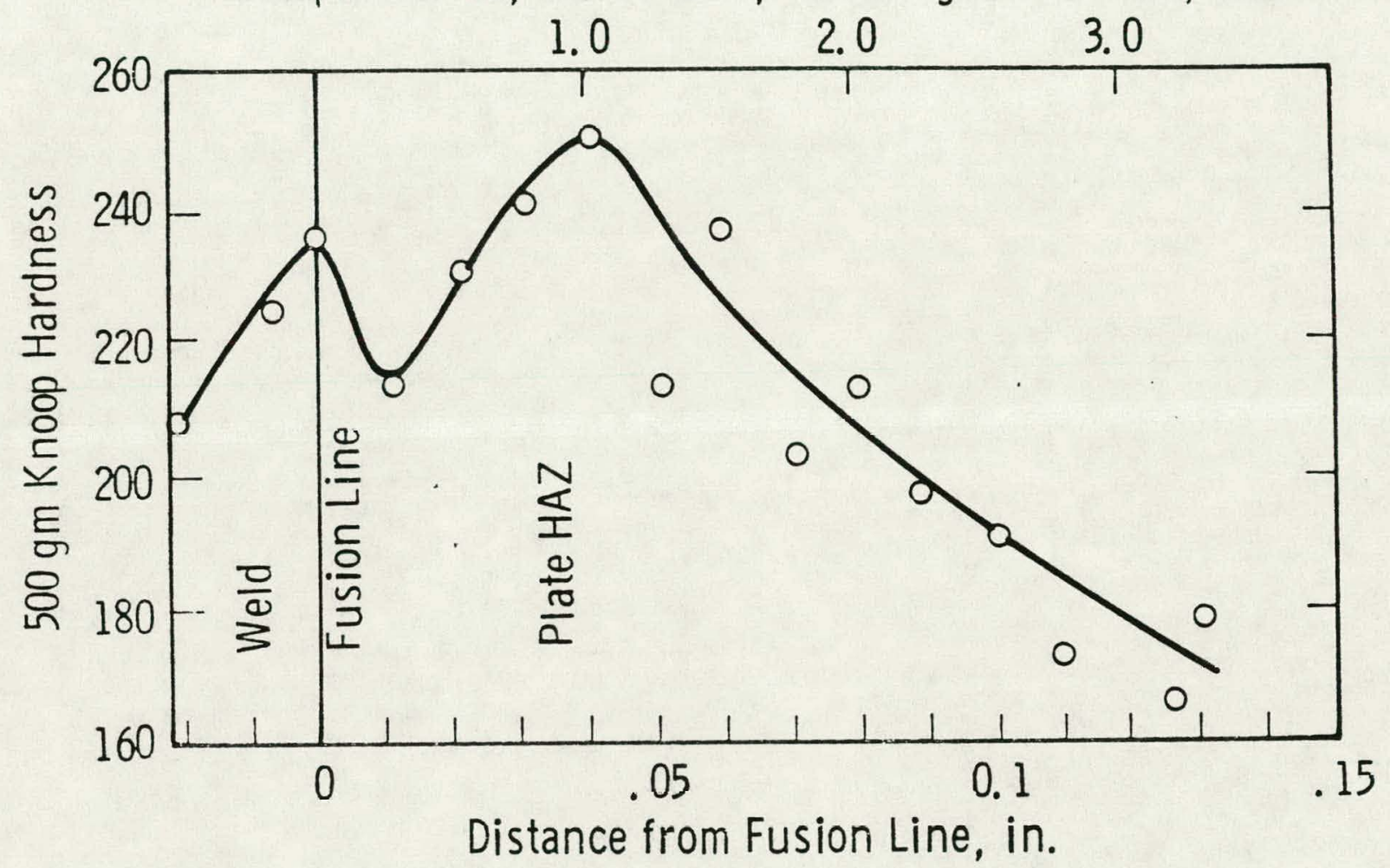

Fig. 3500 gm Knoop hardness as a function of distance from fusion line showing the peak. fiardness in the heat affected zone of the plate. 


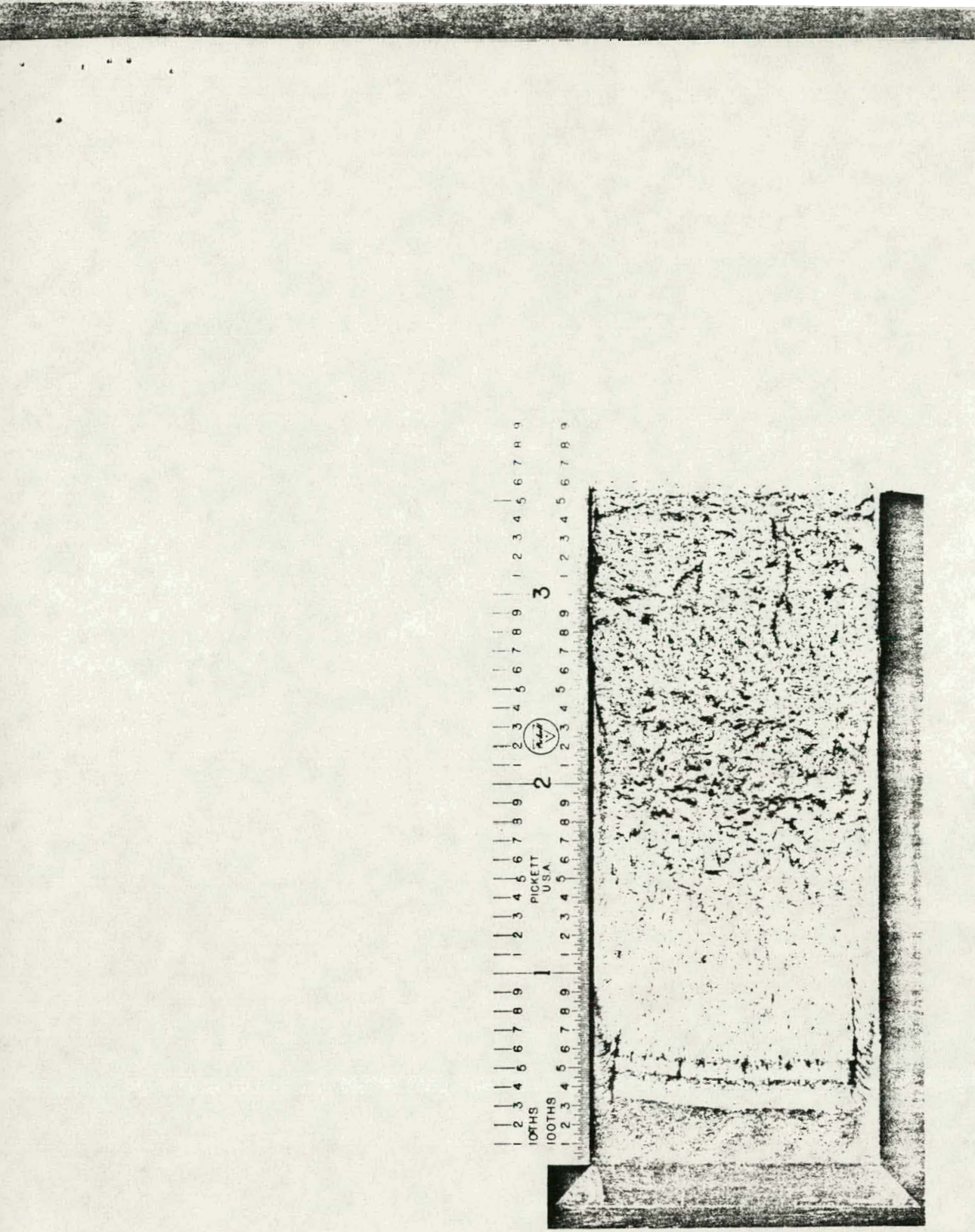

Actual Size

$2 \mathrm{~T}$-WOL with 0.25 in side grooves

Fig. 4 Overview of the fracture surface of sample no. 62 tested in $\mathrm{H}_{2} \mathrm{~S}$. The shear lips due to the crack advancing out of the side-groove plane can be seen on either side. 


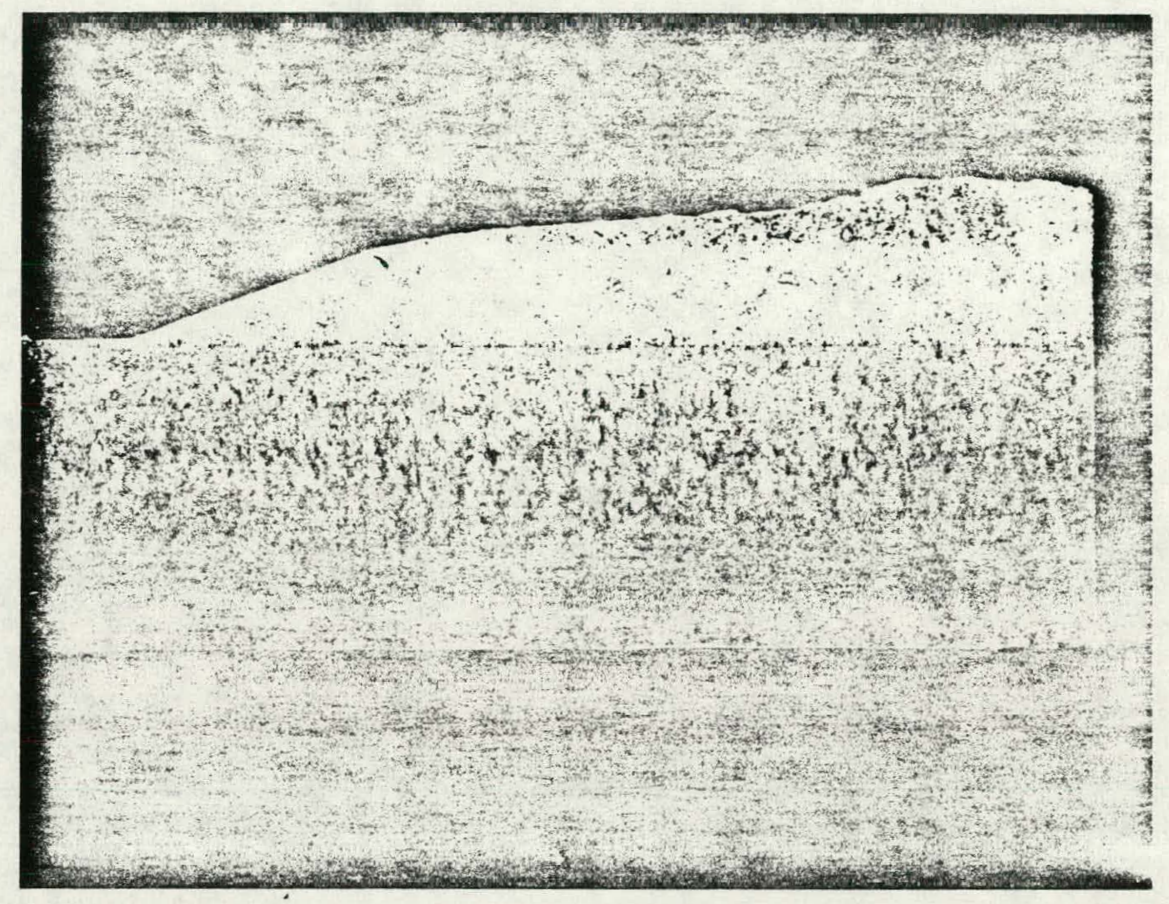

$\mathrm{x} 4$

Fig. 5 A cross section of the center of fracture surface of sample no. 62. This shows that the crack has advanced from the notch on the left away from the fusion zone. 

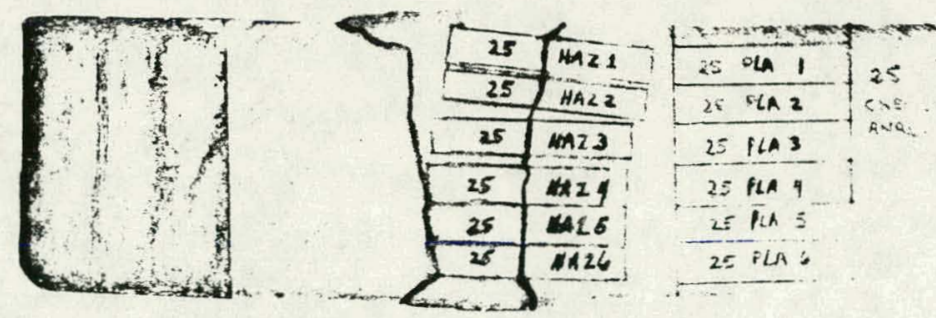

$\mathrm{x}^{\frac{1}{2}}$
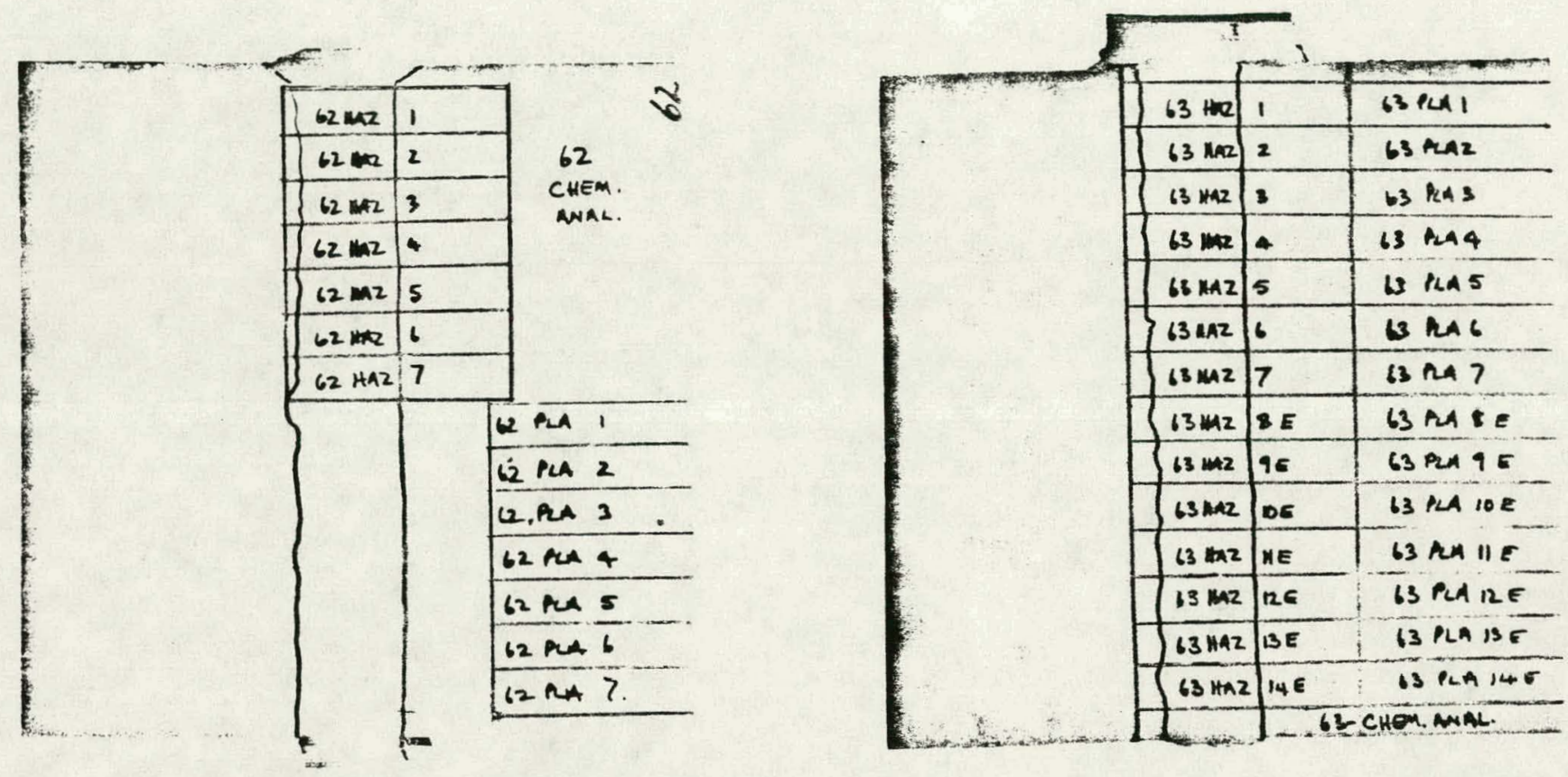

$x^{\frac{1}{2}}$

$\mathrm{x} \frac{1}{2}$

Fig. 6 The location of the Charpy blanks taken from samples 25, 62 and 63. The notch locations were located in the peak hardness zone of the HAZ after the Charpy blanks had been machined and ground to size. 


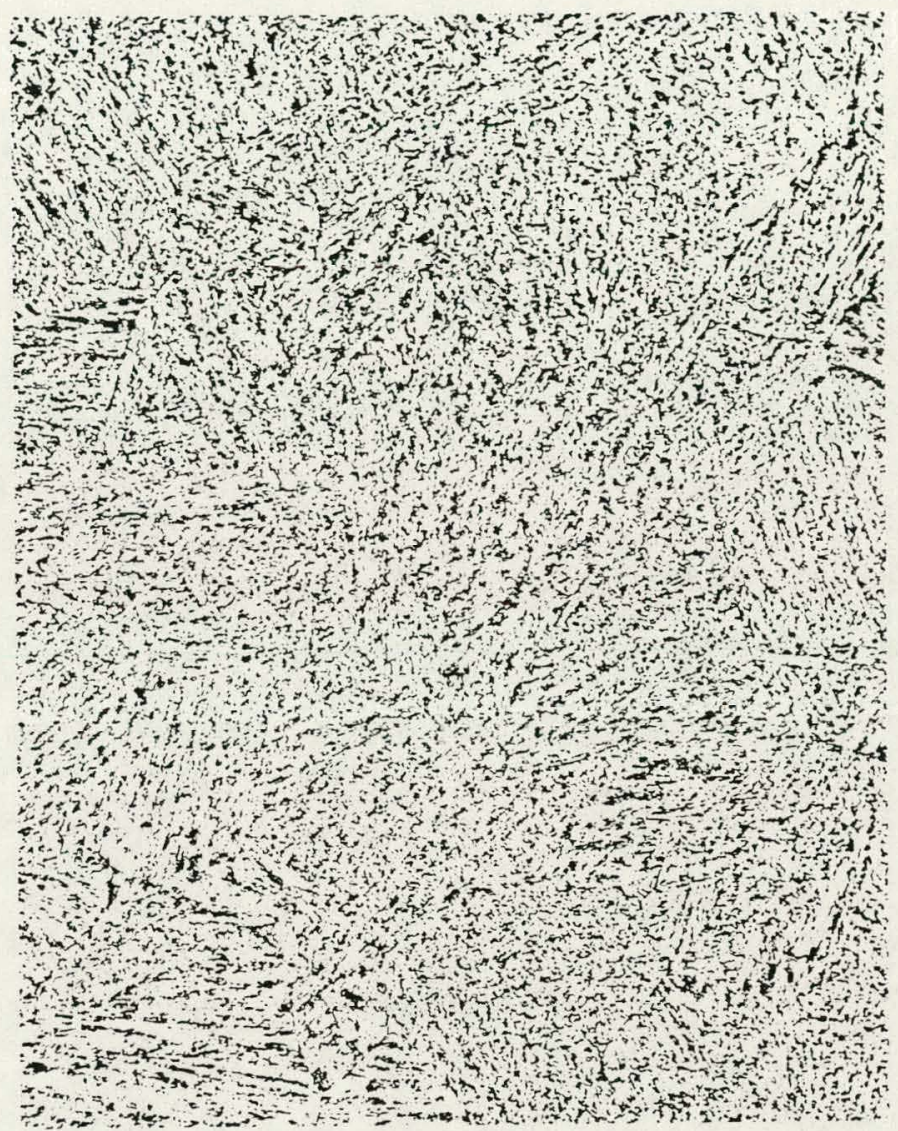

$x 200$

Fig. 7 Typical structure found throughout the cross section of a trial forged sample blank. This sample has not been heat treated after forging. 